LIBRES: Library and Information Science Research

Electronic Journal ISSN 1058-6768

2001 Volume 11 Issue 2; September 31

Bi-annual LIBRES 11N2

\title{
Erotica in Australian Libraries: Are We Negligent Collection Managers?
}

\author{
By \\ Edgar Crook, Librarian \\ Electronic Unit \\ National Library of Australia \\ ecrook@nla.gov.au
}

Literary erotica has existed alongside erotic art and sculpture for as long as there has been the capacity to publish or otherwise transmit the written word. In ancient Greece and Rome the writing of erotic poems and stories were an accepted and popular literary form. Later in the Christian west, writers of erotica were to became subject to the Church, censorship and the law, and whilst there was never a period when there was not production of erotic books, their writings were often driven underground. Today there are few libraries that do not have on their shelves books that were once banned or considered obscene. The works of the Earl of Rochester, Boccaccio and Pauline Reage are now widely available. What was once considered obscene has now seemingly become acceptable by its historicism. Although these authors' and other notable works have survived, comparatively little of the huge amount of privately published erotica has. Some can be found still in private hands, and a little is preserved in libraries. As Henry Ashbee explained in the introduction to his bibliography of erotic literature, published in 1877 and entitled Index Librorum Prohibitorum, when discussing the rarity of erotic material:

"..in addition to "the thousand natural shocks" that books are heirs to, this particular kind is subject to other dangers. They do not usually find their way into public libraries, where they would be comparatively secure, but are for the most part possessed by amateurs, at whose death they are not infrequently burned; and they are always liable to destruction at the hands of the law. Their scarcity then, supposing their original issues to be identical, is very much in proportion to their age; and as society is constantly, so to say, at war with them, the natural course is for them to die out altogether."

The very few libraries that do have reasonable collections such as that held in the 'Private case collection' of the British Library did not themselves collect them but were the beneficiaries of privately owned formed collections. That private collectors amassed 
collections of this material and not libraries was often due to the illegality of publishing this type of material. It has only been comparatively recently that erotica producers have been able to market their wares without fear of prosecution, and so are able to send in copies of their publications as legal deposit. The British Library however itself did not initially seek to have this collection at all. One of the greatest donators of erotica to that library was the aforementioned Henry Ashbee. His collection survived only because he wisely put in a proviso in his bequest that the library could have his outstanding collection of Cervantes original editions if they also pledged to house and preserve his collection of extremely rare erotica.

Although in the past, librarians were or were considered rather tweedy and puritanical, today they are far more likely to be libertarian in outlook. In the United States for example they are, together with the American Civil Liberties Union, often at the forefront of the battle to oppose censorship. An example of the importance to which American librarians place on the freedom to read can be seen by the American Library Association's (ALA) Library Bill of Rights, two points of which state:

III. Libraries should challenge censorship in the fulfillment of their responsibility to provide information and enlightenment.

IV. Libraries should cooperate with all persons and groups concerned with resisting abridgment of free expression and free access to ideas.

An example of how the American library world puts these beliefs into practice is the nationally observed Banned Books Week. This event which has been successfully run in public libraries since 1981, and is organised by librarians together with publishers and other media representatives. Its aim is to highlight the attempts made by persons and organisations to censor books, and promotes counter censorship information and empowerment.

In the United Kingdom there is little history of opposition to censorship. The Library Association Code of Conduct does however state that:

"In places to which the public has right of access, save where the flow of information must be restricted by reason of confidentiality, members have an obligation to facilitate the flow of information and ideas and to protect and promote the rights of every individual to have free and equal access to sources of information without discrimination and within the limits of the law"

This is a clear statement of opposition to censorship, but it is unfortunately tempered by a later section which states:

"Members should not knowingly promote material the prime purpose of which is to encourage discrimination on the grounds of race, colour, creed, gender or sexual orientation."

This later section developed by the liberal to disallow the libertarian, can be used as a tool 
of censorship by a librarian who has the opinion, for example, that sexual matter is in itself discriminatory, or that persons of colour or sexual orientation who appear or don't appear within a works pages are also discriminated against.

In Australia, the introduction of the Broadcast Services (Online Services) Act, 1999 has caused a large growth in censorship in the form of Internet filtering software - although the Act does not require it. Its installation has generally been confined to school libraries(who have been forced into it by education authorities), and university libraries, who have used it merely as an excuse to disallow access as Alex Byrne, Sydney University of Technology Librarian has said "Some universities have responded to this legislation by introducing wide-ranging filtering of Internet access, justifying their measures by reference to the Act and by claims that the cost of receipt of pornographic images is an inappropriate charge against university funds, especially those derived from the public purse. Little concern for intellectual or academic freedom is evident in the statements about such measures." Public libraries have in general not been forced to provide Internet filtering technology, and thankfully, unlike in the United States, there is neither a local grassroots or mainstream political force pushing for its wholesale introduction.

Australian librarians remain generally opposed to censorship and the peak body for librarians, the Australian Library and Information Association (ALIA), actively though not publicly fights censorship through its input into government policy making bodies. The guiding principle in matters of collection development and censorship for Australian librarians appears in the ALIA Statement on Freedom to Read:

"A librarian should not exercise censorship in the selection of materials by rejecting on moral, political, racial or religious grounds alone material which is otherwise relevant to the purpose of the library and meets the standards, such as historical importance, intellectual integrity, effectiveness of expression or accuracy of information which are required by the library concerned. Material should not be rejected on the grounds that its content is controversial or likely to offend some sections of the library's community."

Although laudable, this statement unfortunately is often ignored when it comes to matters of graphic sexuality. Australian libraries do purchase literary erotica produced by the major publishers. This is a reflection of the fact that the market for literary erotica has in the last few years grown exponentially. With the decline of pulp paperbacks of little literary merit which were directed at males, there has been a consequent growth and active marketing push for quality literary erotica aimed at women. The huge popularity of Australianproduced erotic fiction such as Tobsha Learner's Quiver : a book of erotic tales, Linda Jaivin's Eat Me and Susan Johnson's Women Love Sex has created a demand that libraries have been fulfilling. Today, therefore, literary erotica is almost universally accepted and collected in most libraries. However, it is still almost impossible to find any erotic pictorial matter in any public library. Whether public libraries should be providing access to sexually explicit magazines, and how it could possibly be policed is of course an issue which needs further discussion. Considering there is an obvious market for sexually provocative mass

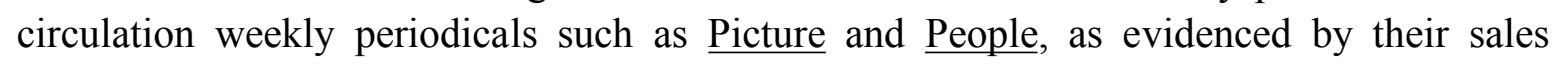


figures, libraries would be serving some sections of society by providing access. Balancing this would be the political reality of having to justify collections to those opposed to this type of material. In the United States at an Intellectual Freedom Round Table discussion as part of the ALA Annual Conference 2000, erotica in libraries was discussed. Though the talk was mainly academic and not representative of ALA policy it still elicited 700 complaints from the public who feared that public libraries were about to start lending porn to children.

Although public libraries have good reasons for not collecting erotica, academic and university libraries which have fewer, are also poor collectors of the erotic. There are a few exceptions however. Flinders University of South Australia

Library houses the archives of the Eros foundation - a sex industry lobby group. Melbourne University has an interesting collection of photographs revealing the composer Percy Grainger's soundly beaten bottom and Sydney University Library has a euphemistically entitled special collection that is housed in the Fisher library. This collection contains the donated private collection of William Deane. His collection contains 1123 works published between 1609 and 1982 most of which are literary erotica. There is also a good number of works current and historic on the subject of flagellation as well as bibliographies and histories of sex and sexual relations. The other major contributor to this collection was Sir Randal Heymanson who donated 1003 items of erotica including sexology. A large part of the erotica in Australia's libraries is housed in a very few libraries, and similar to the situation in the British Library, was not collected but received. What has been preserved, therefore, is not a balanced and wide ranging sample of what has been available over the years but instead what caught the eye or the fetish of several collectors. This is a very poor way for a modern society to preserve its historical and social record. In light of the fact that there are relatively few real collectors and a lack of willing institutional public collecting bodies, it is imperative that Australia's National, university and state libraries collect and so preserve at least a representative sample of the nation's erotic publications.

In the recent past, no libraries collected and so added to the scarcity of these publications. Librarians were apparently unwilling to obtain and preserve legally published erotic material that they considered of no current or future historic, literary, artistic or intellectual value. On all counts this attitude has been proved false. We have moved from Thomas Carlyle's view that history is the study of great men and events to the current concept of social history, which is the study of ordinary people and their lives as they progress through time. The examination of the society and culture of a period today by necessity involves the study of its sexual life. For example, the erotic matter created in the Victorian era has become of great interest to historians. The few remaining sexual diaries and pornographic novels of this era provide many more insights into past lives than the many moral or social novels that are still so widely enjoyed and frequently adapted to television. Aside from its artistic aspects, erotica has not generally been viewed as fulfilling a socially useful function; in fact, it has done so in a very concrete sense. Erotica has had a major if unacknowledged role in the development of our entertainment and electronic media. Photography both still and moving were improved and made commercially viable by the mass market appeal for the means to capture erotic images. The video industry and latterly the Internet have also benefited. Indeed, if not for Internet porn sites we would not have 
had developed so quickly all the interactive video, video conferencing and streaming media capabilities which we currently enjoy.

The mission of the National Library of Australia is "to ensure that a comprehensive record of Australian history and creative endeavor, and a selected record of universal human knowledge is collected and cared for". To fulfill this mission comprehensively the National Library has to collect in every field no matter how seemingly unimportant. Part of the Library's mission therefore, though probably not an overwhelmingly popular one politically or administratively, is to collect in the area of erotica. It may come as a shock to some that the Library's shelves struggle to fit in such weighty volumes as Big ' $n$ ' Bouncy or Bra Busters, but the National Library does hold these and many other contemporary periodicals. Its collection of Australia erotica is, however, historically poor. There are representative works of British, German and French erotica either in original or microfiche dating back to the $1600 \mathrm{~s}$, but a check of the Library catalogue reveals no comparable historical Australian works, despite the fact that Australia, like most other nations, likely produced its share of literary erotica in the $19^{\text {th }}$ century. If it exists, it remains well hidden. The Library currently collects a good representation of the current crop of mainstream literary erotica and over the counter erotic magazines. Very few or none of those publications that are only sold in sex shops are acquired, however, mainly because they are not sent in. Deposit libraries like the National and State libraries often rely on legal deposit, and erotica publishers have never been amongst the keenest providers of free copies. Also, librarians have also not been amongst the keenest studiers of sex shop wares, looking for that missing copy of Australian XXX or other erotic periodical to complement their collections.

Scattered throughout Australian libraries are small collections of Australian mainstream erotic pictorial periodicals, which date primarily from the latter half of the $20^{\text {th }}$ Century. In the 1940 s, there was a freeing up of the ability to purchase openly publications of this sort, apparently for the benefit of WW2 soldiers looking for diversion in the field or in training. Since that time, there has been no lack of Australian produced erotica. Among the popular early titles were Pertinent, Man, and Man Junior, and the later titles Gals and Gags, Maids

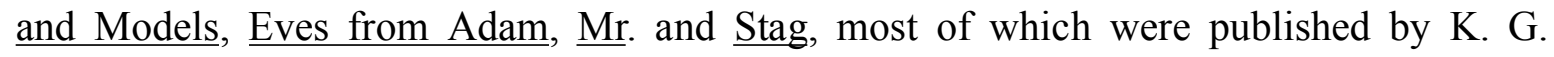
Murray. These publications are quite tame by today's standards - most of them featured in each issue only one or two nude photographs amongst the many clothed ones. The nude photographs were of women in what were termed 'artistic' poses and were often airbrushed to hide the female genitalia, so that they resembled classical sculptures.

Since the 1970s, a decade which saw a huge rise in the open production of erotica, those few collecting libraries have received via legal deposit into their collections a large number of erotic periodicals and other sex-related publications. Many of the periodicals are wholly Australian in origin whilst some are Australian editions of US magazines such as Penthouse, Hustler and Playboy. There are regional versions of these periodicals such as the Queensland edition of Penthouse and the restricted and unrestricted versions of Hustler, which are sold in different states to comply with different legal constraints.

Since the early 1970s some libraries have also collected gay male erotica. When the 
production and dissemination of homoerotic images became legal and actual with the publication of titles such as Stallion (1973-4), Naked Teens (1974) and Australian Golden Boys (1973-4), libraries began to form collections of gay pictorial matter featuring photographs of nude men. Although no library has been able to collect exhaustively in this area, the chances of gay erotica not being preserved and therefore lost are mitigated by the efforts of the Australian Lesbian and Gay Archives in Melbourne which has collected over 15,000 items (though not all erotica) since its inception in 1978.

Australia does not have a centre like the Kinsey Institute in the United States or Archiv für Sexualwissenschaft at the Robert Koch Institute in Germany that collects and preserves sexual material deemed transgressive in society. The preservation burden therefore rests on the Australian National, State, and university library sector to attempt to maintain a solid and comprehensive collection of this type of material. Australia has historically had a very successful concept of a distributed national collection whereby individual libraries collect in particular subjects in strength, which other libraries can then also benefit from. Unfortunately no library in Australia has developed a comprehensive collection of erotica. Whilst this is the case, the situation will remain that there are small amounts of material spread across Australia without context and often subject to over-burdensome access restrictions. The National Library of Australia and State libraries are probably not the best places for this possible future collection, though they should be more proactive in seeking material that it is due to them under legal deposit. Australia therefore needs one of its universities to take it upon itself to found and house an erotic national collection, though in this time of shrinking library budgets, it is unfortunately highly unlikely that this will happen.

The erotica industry today produces an often hidden but still very substantial amount of all published material. Erotica has become accepted as part of the legitimate publishing world as evidenced by the 300,000 copies of Australian adult sexual publications sold weekly. For Australian libraries not to collect at least a sample of this production will severely diminish the future historical record and distort the true sexual nature of the society we live in. It is important that libraries collect this material. If not for now, then as an indicator of social mores, standards and public attitudes to matters sexual for the future reader, the social scientist, historian or sexologist a hundred or a thousand years hence.

\section{Bibliography}

American Library Association, Banned Books Week, [online] http://www.ala.org /pio/presskits/bbwkit/bbw00release.html

American Library Association, Library Bill of Rights, [online], http://www.ala.org /work/freedom/lbr.html

Ashbee, Henry, [Pisanus Fraxi], Index librorum prohibitoru, being notes bio- biblio- iconographical and critical, on curious and uncommon books, London, 1960. 
Australian Library and Information Association, Statement on freedom to read, [online] http://www.alia.org.au/policies/freedom.to.read.html

Byrne, Alex, The story of Yongyi: intellectual freedom and academic libraries, [online] http://www.lib.uts.edu.au/mkts forum/AB transcript.html

Eros Foundation, Between the Sheets: sex facts from the suburbs, [online] http://www.eros.com.au/btsheets.php, 2000.

Hyde, H. Montgomery, A history of pornography, London, Heinemann,1964.

Inge, Thomas M. (ed.) Handbook of American popular culture, 2nd ed., New York, Greenwood Press, 1989.

Kendrick, Walter M., The secret museum: pornography in modern culture, New York, Viking, 1987.

Kinsey Institute for Research in Sex, Gender and Reproduction, History of the Institute, [online] http://www.indiana.edu/ kinsey/abtki.html

Library Association, Code of Conduct, [online] http://www.la-hq.org.uk/directory/about/conduct.html

Marcus, Steven, The other Victorians : a study of sexuality and pornography in mid-nineteenth-century England, London, Corgi, 1970.

National Library of Australia, Directions for 2000-2002, Canberra, [1999].

Sova, Dawn B, Literature suppressed on sexual grounds, New York, Facts on File, 1998.

Stroebel, L and Zakia, R. (eds.), The Focal encyclopedia of photography, $3^{\text {rd }}$ ed., Boston, Focal Press, 1993.

This document may be circulated freely

with the following statement included in its entirety:

Copyright 2001

This article was originally published in

LIBRES: Library and Information Science

Electronic Journal (ISSN 1058-6768) September 31, 2001

Volume 11 Issue 2.

For any commercial use, or publication

(including electronic journals), you must obtain 
the permission of the author.

Edgar Crook, Librarian

Electronic Unit

National Library of Australia

ecrook@nla.gov.au

To subscribe to LIBRES send e-mail message to

listproc@info.curtin.edu.au

with the text:

subscribe libres [your first name] [your last name]

Return to Libres 11n2 Contents

Return to Libres Home Page

CRICOS provider code: $00301 \mathrm{~J}$ 